\title{
蓄熱槽の合理的運転管理のための冷暖房負荷予測 \\ HEATING AND COOLING LOAD PREDICTION FOR THE RATIONAL MANAGEMENT OF THERMAL STORAGE TANK OPERATION
}

\author{
吉田治典* \\ Harunori YOSHIDA
}

\begin{abstract}
Thermal storage tanks are used to store thermal energy that is considered to be used up on the following day. However if heat is stored excessively, some of it will be lost due to heat transfer through walls and slabs surrounding the tank. To avoid the energy loss related to thermal storage tanks, predicted air-conditioning load required for the following day can be one of the indispensable information because rational operation of a heat source system with thermal storage tanks can be achieved utilizing the information.

In this paper the method to predict the air-conditioning load is proposed. The method consists of two stages; weather data prediction and load prediction. The method was applied for the operation of the heat source system of a real building and the measured results are shown here. The error of the prediction was about $12 \%$ for winter and $29 \%$ for summer. The low accuracy for summer should be improved, however, it is also due to the highly unpredictable summer weather when the trial was made.
\end{abstract}

Keywords: thermal storage tank, air-conditioning load prediction, weather data prediction

蓄熱槽，空調熱負荷予测，気象デー夕予测

1. 序

空調用熱源での蓄熱槽の利用は、電力の負荷平準化、発電所の効 率運転、空調用熱源の縮小、熱負荷に対する弾力的運用など、その 効用は周知のとおりである。しかし、設計方法に比して蓄熱槽の合 理的な運用方法については、なお問題が多く残されているようであ る。

蓄熱運転は次のように行われることが多い。1）電力会社が決めた 深夜電力のタイムフレームに従って毎晚早い時刻から熱源を運転す るため、特に中間期に蓄熱は空調運転開始よりかなり前に完了す る。2）蓄熱槽には能力限界までフルに蓄熱されるが、蓄熱された熱 が次の日に十分使われず残る。3）蓄熱の温度レベルは冷房・暖房の 全期間を通して一定（設計值）とされる。

こうした運転は、蓄熱槽からの少なからぬ熱損失を招いたり、冷 凍機やヒートポンプの効率よい運転がなされないなど、省エネル ギーの観点から好ましくない面が多々ある。この欠点を補うため、 オペレータは経験と勘で蓄熱運転開始時間や運転時間の長さを決定 したり、蓄熱温度レベルを調整したりすることもあるが、実態は必 ずしも満足のゆく結果ではないといわれる。

この困難の理由の一つに、蓄熱運転の翌日に生ずる未来の熱負荷 予測の技術が未熟で、現実のシステムへの応用も過渡的な段階にあ るため、蓄熱槽の合理的な運転が難しいことが上げられる。このよ
うな背景から、本研究では、熱負荷予測手法の一手法として筆者が開 発した手法を提案し、実際の建物の負荷予测にその手法を応用した例 を報告する。

ところで最近、電力料金は、ピーク時刻の高料金制度の導入な ど、需要と供給の関係からトータルな最適化を目指す中で自由化の方 向にある。今後はわが国でも、欧米に見られるように、時々刻々料金 が変動するという究極の自由化も考えられる。こうして、電気だけで なくカスス・オイルのエネルギー源、コジェネレーションなど、空調熱 源以外のエネルギー供給システムも視点に入れたトータルな最適運転 が課題となり得る。この場合、蓄熱槽を持たないシステムであって も、数時間先の短期的な予测の必要性があり、熱負荷予测手法の確立 は重要と考えられる。

\section{2. 手法}

熱負荷予測の手法は、どのような情報とアルゴリズムを用いるか で様々のバリエーションが生まれる。ここでそれらを概括しながら本 手法の特長を示す。

予測に用いることのできる情報には、過去の観測情報と未来の予 報情報の 2 つがある。過去の観測情報は、一般に、熱負荷、室温・湿 度などの室内環境デー夕、空調運転スケジュール、外気温などの外界 気象デー夕、使用エネルギー量などで、これらは中央監視盤やエネル 
ギー管理システム（BEMS：Building Energy Management System）で 集稓されることが多い。未来の予報情報には、気象台やその他の機 関から出される天気予報、ならびに将来の内部発熱負荷の基となる 使用パターンや付随する空調運転スケジュールなどがある。

天気情報には「晴れ」や「量り後雨」のような予報天気概況の他 に、最低湿度、風向・風速などの予測值がある。近年、予報の信頼 性がかなり高くなっているため、多くの熱負荷予測手法で予報を利 用している1),22), 5),フ-11)。しかし大半の手法では、翌日の最高・最低気 温を利用するに止まっている。もし、気温・日射・湿度の生起に高 い相関があれば、予测値として気温のみを用いても他の要素の予測 は間接的に組み入れられたことになり必要性は低い。しかし、気象 テータの解析によれば、夏は気温と日射に正の相関があるが冬には ない、湿度と日射は冬に負の相関があるが夏にはない、気温と湿度 は一年中正の相関がある、など相互の関係は確定的ではなく12)、要素 ごとの予测を別個に組み入れる方法が精度向上の意味からは好まし い。そこで本手法では「晴れ」などの天気概況予測の利用と、最低 相対湿度でなされる湿度の予测値の利用を図った。

熱負荷の予測にはどの手法も何らかのモデルを利用している。手 法の差はモデ構成とパラメータを見いだすアルゴリズムにある。 大別すれば、熱負荷生成の内部構造を無視して、熱負荷と熱負荷に 関係が媣い情報とを経験的・染意的に捉えるモデル、熱負荷の発 生機構をベースにしたモデルがある。前者をブラックボックスモデ ル、後者をフィジカルモテルとして区別することもできる。ブラッ クボックスモデルはさらに線形モデルと非線形モテルに分けられ、 前者はARMAXやARIMAモテルを利用して 6), 7)、後者は多次式や ニューラルネットワークなどを利用して棈成される11)。一方、フィジ カルモデは熱負荷計算の体系を基に応答係数を介して線形モデル を構成するもの 3$), 9) 、$ 線形な近似モデルを構成する本手法などがある 1), 2)。

本報を含む少数の手法（文献 $1,2,3,9$ ）が他の手法と大きく異なる のは建物躯体の蓄熱負荷を陽にモテルに組み入れている点で、特に 土・日に運転が停止されたり、極端な場合には不定期な運転スケ ジュールで空調されても原理的に対応可能である。これに対して他 の多くの手法は、蓄熱作用の効果を曜日情報という経験的な因果関 係で対処しているため、一般に、残業、特別休日など、典型的なス ケジュールから逸脱するに従い対応が難かしくなる傾向にある。

さて、本手法では予测を2段階に分けて行う。第1段階は気象デー タの予測であり、第2段階はその気象デー夕を基にした熱負荷の予測 である。この2段階の予測手法は、いわゆる熱負荷計算のアルゴリズ ムと同様の流れを持つことを意図して權成した。このモデルの採用 により上記した柔軟性が得られると共に、気象予测、熱負荷予测そ れぞれの精度を分離してモデルを評価・改善できるというメリット がある。

\section{2-1 気象テータの予測}

まず、第1段階の気象テータの予測について述へる。熱負荷に影響 する気象デー夕には、気温、日射、湿度、風向・風速、長波長放射 などがある。本研究ではこの中から気温、日射、湿度を取り上げ た。通常、長波長放射の熱負荷への影響は大きくない。風向・風速 の影響は建物によっては大きいこともあるが本研究ではこれを無視
する。なお、気象データの予測では、筆者による気象データのモデ ル化の研究で得られた知見を用いている12), 13)。

予測情報としての気象データは天気予報を基に作成するが、次の 問題がある。

1）一般に、温度、湿度の予報は気象台の存在する地点（以後、参 照地という）の予測値であり、また、天気の場合は建物の存在地点 （以後、現地という）を含むかなり広い地域（例えば神奈川県西部 など）の概況予報である。つまり、「現地」に直結する予報値や概 況が直接得られる訳ではないため、参照地の予報と現地の予報の関 係づけが必要となる。

2）予報は、気温に対して最高・最低気温、天気に対して「晴れ」 などの概況、湿度に対して翌日の最低相対湿度でなされ、24時間先 までの時々刻々の気温、日射、湿度のデータが直接与えられるもの ではない。つまり、これらも何らかの変換が必要である。

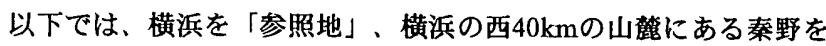
「現地」とし、横浜の気象台の予報值から秦野の気象デー夕を予測 するという具体例を示しながら、本研究で用いる気象データの予測 法を述べる。

前提条件：

1）予測を行う日の最低1日前から、参照地ならびに現地建物で観測 した気象データ（外気温、湿度、水平面全天日射量）、および 現地を含む地域の天気予報が既知とする。

2）予測は午後 9 時の天気予報を用い、午後10時から翌日にかけて24時 間先までの予测を行う。ただ、天気予報は当日の早朝にも再度 出されるので、当日の短期予测には同じ手法を適用し精度を高 めることもできる。

\section{A）気温予測の手順}

1）日周期成分

予報から $n$ 日前の現地観测気温 $\theta_{N-n, j}$ （ $N$ : 予報日、 $j:$ 時刻）を 用いて $K$ 日間の期間平均值 $\bar{\theta}$ を算出する。次にこの値を用いて日周 期成分 $\tilde{\theta}_{j}$ を求める（式(1)）。この成分は季節と共に変化するので、 平均を取る期間 $K か ゙$ 余りに長くなると不適切となる。種々の気象 デー夕の解析の経験から最大 30 日程度でよいと考える12), 13)。

$\bar{\theta}_{N}=\frac{1}{(K \times 24)} \sum_{n=1}^{K} \sum_{j=1}^{24} \theta_{N-n, j} \quad \tilde{\theta}_{N, j}=\frac{1}{K} \sum_{n=1}^{K} \theta_{N-n, j}-\bar{\theta}$

\section{2）日最高気温・最低気温}

現地と参照地（添字 $R$ で示す）の日最高気温・最低気温の関係を 線形関係で表せると仮定し、係数を最小二乗法により見いだす（次 式。

$\theta_{N-n, \max } \cong a_{\max } \theta_{(R) N-n, \max }+b_{\max }$

$\theta_{N-n, \min } \cong a_{\min } \theta_{(R) N-n, \min }+b_{\text {min }}$

例として、横浜 (参照地) と秦野 (現地) の観測記録（1985年） から求めた係数を以下に記す。

\begin{tabular}{|l|c|c|c|c|}
\hline & \multicolumn{2}{|c|}{$a[-]$} & \multicolumn{2}{c|}{$b[K]$} \\
\hline & $\max$ & $\min$ & $\max$ & $\min$ \\
\hline 夏期 & 0.960 & 0.924 & 0.458 & 0.637 \\
\hline 冬期 & 0.936 & 1.089 & -0.555 & -0.979 \\
\hline \multicolumn{3}{|c|}{ 表-1 } \\
式(2)の係数（秦野）
\end{tabular}


気候が変化しない限り過去のデー夕を多量に用いるほど係数の信 頼度は高くなるので、データが十分長期（数年間）にわたって蓄積 されれば、係数を月ごとに求め、精度を向上させるのが良いであろ う。

\section{3）時刻別予測值}

観测值から、1〜24時の日平均気温 $\theta_{a v e}$ を求めた結果、現地と参照 地ともに、最高気温と最低気温の平均値で近似できることが判つ た。つまり

$\theta_{N, \text { ave }} \cong\left(\theta_{N, \text { max }}+\theta_{N, \text { min }}\right) / 2$

この平均値は文献 12,13 でいうところの、年周期成分と確率的中周 波数成分の和に相当し、サンプリング時刻としては時刻12時で表さ れる值である。さて、気温の時刻袩動はこの值に確定的日周期成分 $\tilde{\theta}_{j}$ と確率的高周波数成分とを加えてモテル化できるが13)、この高周 波成分は微細に振動する成分ゆえ無視することにより、将来の気温 を近似的に次式で予测する。

$\hat{\theta}_{N, j}=\theta_{(N-1), a v e}+\frac{(j-12)\left(\hat{\theta}_{N, \text { ave }}-\theta_{(N-1), a v e}\right)}{24}+\tilde{\theta}_{j} \frac{\Delta \hat{\theta}_{N}}{\Delta \tilde{\theta}}$

ただし、変数の記号^は予測值を示す。また、

$\Delta \tilde{\theta}_{N}=\max \left(\tilde{\theta}_{N, j}\right)-\min \left(\tilde{\theta}_{N, j}\right) 、 \Delta \hat{\theta}_{N}=\hat{\theta}_{N, \max }-\hat{\theta}_{N, \min }$

ここで、jは時刻であり、翌日の場合は実䟢の時刻に24時間を加え る。式(4)の右辺第1項は(N-1)日の平均気温、第2項は(N-1)日からN日 へ向かう平均気温の線形的変化、第3項は平均的日周期成分を振幅調 整して得た日周期成分を意味する。また、予測開始の時間が午後9時 ではなく翌日の朝で、既に当日早朝の最低気温が観測されていれ ば、 $\hat{\theta}_{N, \text { ave }} 、 \Delta \hat{\theta}_{N}$ はその值を基にして求める。

\section{B）湿度予測の手順}

湿度の予報は翌日の最低相対湿度 $\hat{\phi}_{N, \text { min }}$ でなされる。そこで、最 低相対湿度が最高気温時に生ずると仮定し、その時の混合比（絶対 湿度）を求める。また、最高気温は午後2時に生ずることも仮定す る。混合比の日周期変動は少ないので無視し、各時の混合比を次式 で線形的に予测する。つまり、式(4)の第3項を無視することに相当す る。

$\hat{x}_{N, j}=x_{(N-1), a v e}+\frac{(j-12)\left(\hat{x}_{N, a v e}-x_{(N-1), a v e}\right)}{24}$

$$
\text { ただし、 } \hat{x}_{N, \text { ave }}=f_{S}\left(\hat{\theta}_{N, \max }, \hat{\phi}_{N, \text { min }}\right)
$$

ここで、 $f_{S}$ は乾球温度と相対湿度から混合比を求める関数であ る。

\section{C）日射予測の手順}

天気と日射量は相関が高いので、日射量の予测は天気概況の予報 を用いる。天気概洒は「晴れ時々是り」など、天気の組み合わせで 予報され、20以上もの種類がある。そこで、天気を表-2のよう区分 し、実際に生じたある日の天気（予報ではない）で生じた基準化日 射量（日積算全天日射量を日積算大気圈外日射量で除した値）の日
平均值と標準偏差の関係として整理し図-1.1に示す。ただし参照地 （横浜）の日射記録はないので、現地（秦野）の日射量との関係で ある。

このように天気区分から日射を推定すると相当の偏差を持つこと が判る。しかし、偏差を減らすために区分数を增しても各区分内の データ数が少なくなるため、結果的には必ずしも偏差は減少しない ことが確認された。この検討から、区分数6を最適と判断した。

\begin{tabular}{|c|c|}
\hline 区分 & 天気 \\
\hline 1 & 快晴、晴れ \\
\hline 2 & 薄暴り、晴れ（一時、時々）（塄り、雨） \\
\hline 3 & 晴れ後暴り、暴（後、一時、時々）晴れ \\
\hline 4 & 暴り、暴り（時々、一時）晴れ（時々、一時）雨 \\
\hline 5 & 暴り（後、一時、時々）雨、雨（後、一時、時々）暴り \\
\hline 6 & |雨、雨強 \\
\hline
\end{tabular}

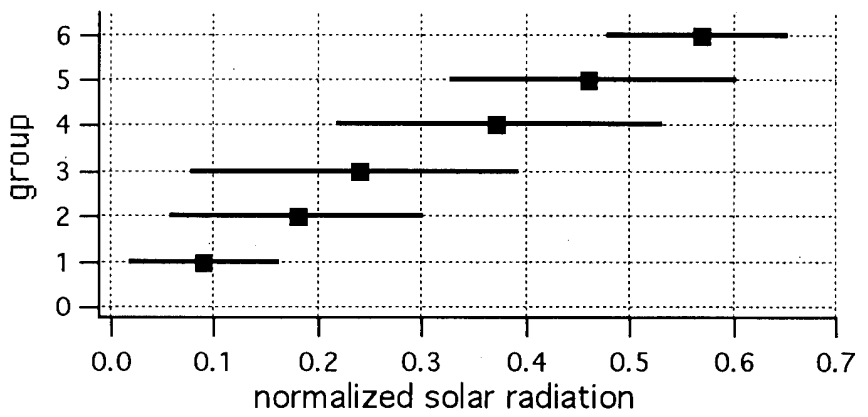

图-1.1実際に生じた天気区分と基準化日射

(口：平均、実線：標準(扁差)

\begin{tabular}{c|ccc}
\hline 区分 & $\bar{广}^{+}$-夕数 & $\eta_{\mathrm{N}}$ & 偏差 \\
\hline 1 & 59 & 0.598 & 0.059 \\
2 & 92 & 0.486 & 0.092 \\
3 & 115 & 0.380 & 0.115 \\
4 & 98 & 0.283 & 0.098 \\
5 & 90 & 0.178 & 0.090 \\
6 & 36 & 0.079 & 0.036
\end{tabular}

表-3.1 天気区分と平均基準化日射量 $\eta_{\mathrm{N}}$

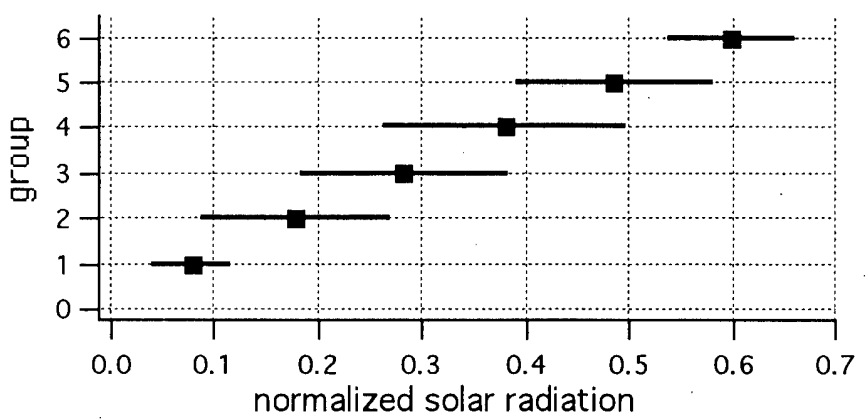

図-1.2 天気予報による天気区分と基準化日射

\begin{tabular}{c|ccc}
\hline 区分 & $\bar{T}^{\prime}$-夕数 & $\eta_{\mathrm{N}}$ & 偏差 \\
\hline 1 & 36 & 0.568 & 0.085 \\
2 & 57 & 0.464 & 0.136 \\
3 & 44 & 0.373 & 0.156 \\
4 & 45 & 0.237 & 0.153 \\
5 & 27 & 0.177 & 0.121 \\
6 & 11 & 0.088 & 0.067
\end{tabular}

表-3.2 天気予報区分と平均基準化日射量 $\eta_{\mathrm{N}}$ 
偏差の原因には次のようなものが考光られる。

1) 言葉によって天気を表すことの限界。

2) 参照地と現地で必ずしも天気が一致しない。

3) 本予测方法では、終日一定の割合で大気圈外の日射が減衰し地 表に到達するとしており、水平面日射の時間変化は正午を中心 にプロファイルが対象となる。つまり、「晴れ後秱り」という 予報において、午前中の日射を增すという細かな予测操作はし ていない。

ただ、上記の結果は横浜の221日間の天気を基に検討したものであ るが、テー夕数が増えれば区分数やブロファイルをより細かくして 精度の向上を図れる可能性も残されている。しかし現在、予報值は 記録データとして公開されておらず、多量のデータ収集は簡単では ない。従ってある地点で自前でデータを集積し分析を別途行う必要 がある。このように、多量のデータが得られた場合の天気区分の最 適化は今後の課題である。

ところで、予報はある確率で外れる。図-1.2は、秦野が含まれる地 域（神奈川県西部）の天気予報を基に作成した図-1.1と同様の図であ る。この場合天気予報が外れることに起因する予測の偏差が更に加 わる。

以上より、本研究の日射の求め方を整理する。

1）天気予報を基に明日の天気の区分を表2で決め、表3.2から平均基 準化日射量 $\eta_{N}$ を求める。

2）次式で水平面全天日射量を予測する。

$J_{N, j}=\frac{1}{L^{2}} \eta_{N} I_{0} \sin h_{j}$

ここで、 $I_{0}$ : 太陽定数、 $h_{j}$ : 太陽高度、 $L$ :太陽と地球の距離／ 太陽と地球の平均距離

なお、表3.2は、参照地（横浜）と現地（秦野）という特定の地域 のデータから得られた值である。従って、原理的には表3.2は地点が 変われば別途作成する必要がある。しかし、1) 基準化した日射量の ため太陽位置が変わっても近似的には適応可能なこと、2) 後述する ように、日射量による熱負荷への影響を決定するパラメータは予測 過程で同定するため、天気区分間の基準化日射量の比が保たれてい れば近似的に使用可能であること、の理由により、他の地域にも適 用できる可能性は高いと思われる。

\section{2-2 熱負荷の予測}

熱負荷予測のモテルを簡単化するため、次の仮定をおく。1）対 象となる空調ソーンは等温な一室とみなす、2）空を通過する日射 は瞬時に熱負荷になる、3）壁体伝熱には熱水分のインターラク ションがない。これから次式の熱バランス式を立てる。

$c_{p a} G_{R} \frac{d \theta_{R}}{d t}=\sum_{L} \int_{0}^{\infty} \varphi_{T, L}(\tau) \theta_{0, L}(t-\tau) d \tau+\int_{0}^{\infty} \varphi_{A}(\tau) \theta_{R}(t-\tau) d \tau$

$+\sum_{L} \int_{0}^{\infty} \varphi_{S, L}(\tau) J_{L}(t-\tau) d \tau+c_{p a} G_{o}(t)\left\{\theta_{0}(t)-\theta_{R}(t)\right\}$

$+q_{S R}(t)+q_{S A}(t)$

(6)

ここで、 $c_{p a}$ : 空気の比熱、 $c_{p a} G_{R}$ : 室（建物）の熱容量、 $G_{o}$ :
隙間風量（筫量）、 $J_{L}$ : 方位 $L$ の日射量、 $q_{S R}$ : 内部発熱、 $q_{S A}$ : 空 調で与えられる顕熱、 $\varphi_{T}$ : 外気温に対する外壁の貫流熱のインパル 応答、 $\varphi_{A}$ : 室温に対する吸熱のインパルス応答、 $\varphi_{S, L}:$ 方位 $L へ$ の空の日射が熱負荷となる係数、 $\theta_{R}$ : 室温、 $\theta_{0}$ : 外気温、 $\theta_{0, L}:$ 方 位 $L$ 等価外気温、 $t$ : 時間

また、水分負荷 $x$ による潜熱負荷は $x\left(i_{o}+c_{p v} \theta\right)$ である（ここ で、 $c_{p v}, \theta$ はそれぞれ、水蒸気の定積比熱と温度）。この潜熱負荷 を $\left(x i_{o}\right)$ で近似することにすれば、次式の水分バランス式を得る。

$i_{o} G_{R} \frac{d x_{R}}{d t}=i_{o} G_{o}(t)\left\{x_{0}(t)-x_{R}(t)\right\}+q_{L R}(t)+q_{L A}(t)$

ここで、 $i_{o}: 0^{\circ} \mathrm{C}$ の水の蒸発潜熱、 $q_{L R}$ : 潜熱発生、 $q_{L A}$ : 空調で 与えられる潜熱、 $x_{R} 、 x_{0}$ : 室内、室外空気の混合比

式(6)と(7)を加え、空気の比エンタルピーを $h \cong c_{p a} \theta+i_{o} x$ で近似 すれば、

$G_{R} \frac{d h_{R}}{d t}=\sum_{L} \int_{0}^{\infty} \varphi_{\tau, L}(\tau) \theta_{0, L}(t-\tau) d \tau+\int_{0}^{\infty} \varphi_{A}(\tau) \theta_{R}(t-\tau) d \tau$

$+\sum_{L} \int_{0}^{\infty} \varphi_{S, L}(\tau) J_{L}(t-\tau) d \tau+G_{o}(t)\left\{h_{0}(t)-h_{R}(t)\right\}+q_{R}(t)+q_{A}(t)$

ここで、 $q_{R}$ : 室内の全熱発生、 $q_{A}$ : 空調が与える全熱

式（8）を離散化して、

$$
\begin{aligned}
& G_{R}\left(h_{R, j}-h_{R, j-1}\right)=\left\{\sum_{L} \sum_{p=0}^{\infty} \Phi_{T, L, p} \theta_{0, L, j-p}+\sum_{q=0}^{\infty} \Phi_{A, q} \theta_{R, j-q}\right. \\
& \left.\quad+\sum_{L} \sum_{r=0}^{\infty} \Phi_{S, L, r} J_{L, j-r}+G_{o, j}\left(h_{0, j}-h_{R, j}\right)+q_{R, j}+q_{A, j}\right\} \Delta t
\end{aligned}
$$

本式に次の近似を導入し式(10)を得る。

1) 比エンタルピーは温度と混合比の関数であるが、室内湿度の場 合は変動が小さいことから温度のみの関数として近似する。つ まり、

$G_{R}\left(h_{R, j}-h_{R, j-1}\right) \cong a\left(\theta_{R, j}-\theta_{R, j-1}\right)$

2) 漏入外気の比エンタルピーも温度のみの関数とする。また漏入 空気量は一定と仮定する。この仮定による誤差は漏入風量が少 なりれば無視できる。つまり、

$G_{o, j}\left(h_{0, j}-h_{R, j}\right) \cong a_{l}\left(\theta_{o, j}-\theta_{R, j}\right)$

3) 室内発生熱 $q_{R}$ は通常観測していないので時刻変化のプロファイ $ル \zeta_{R}$ を既知とし、その大きさ (レペル) $a_{R}$ を末知保数とし表 す。つまり、

$q_{R, j}=a_{R} \zeta_{R, j}$

4）予測したい熱負荷は熱源で要求されるシステム全体の熱負荷 $q_{A C}$ であり、これは室の熱負荷 $q_{A}$ と、外気導入負荷、ダクトやパイ プからの損失などの熱負荷 $q_{0}$ の和である。ここで $q_{0}$ は外気と室 内のエンタルピー差 $\Delta h$ で表せる外気導入負荷に比例するものと 仮定し、外気導入のスケジュール $\zeta_{o, j}$ は既知として、3)と同様に レベル $a_{o}$ を末知とする式で表す。 $q_{o} \cong a_{o} \zeta_{o, j}\left(h_{0, j}-h_{R, j}\right)=a_{o} \zeta_{o j} \Delta h_{j}$

5) 式(9)のコンボリューション項は有限項で打ち切る。

以上の係数 $a$ を部分的に再定義することにより次式を得る。 


$$
\begin{aligned}
q_{A C, j}= & \sum_{L} \sum_{p=0}^{p} a_{\tau, L, p} \theta_{0, L, j-p}+\sum_{q=0}^{q} a_{A, q} \theta_{R, j-q} \\
& +\sum_{L} \sum_{r=0}^{r} a_{S, L r} J_{L, j-r}+a_{R} \zeta_{R, j}+a_{o} \zeta_{o, j} \Delta h_{j}+\varepsilon_{j}
\end{aligned}
$$

本式は空調負荷 $q_{A C}$ が誤差 $\varepsilon_{n}$ と既知変数の積の線形和で表される ことを示す。ここで、各項に含まれる係数 $a$ と積和の次数 $p, q$ は末 知である。

さて、係数 $a$ は誤差を白色雑音と見なし、以下の最小2乗法により 逐次推定する。

まず次のようにべクトルを定義する。

$$
\begin{gathered}
a=\left(a_{T, 1,1}, \cdots, a_{T, L, p}, a_{A, 0}, \cdots a_{A, q}, a_{S, 1,0}, \cdots, a_{S, L, r}, a_{R}, a_{o}\right) \\
\varphi_{j}=\left(\theta_{0,1, j}, \cdots, \theta_{0, L, j-p}, \theta_{R, j}, \cdots, \theta_{R, j-q}, J_{1, j}, \cdots, J_{L, j-q},\right. \\
\left.\zeta_{R, j}, \zeta_{o, j}, \Delta h_{j}\right)
\end{gathered}
$$

次式を逐次適用し、係数ベクトル $a$ を推定する。

$$
\left\{\begin{array}{l}
\hat{a}_{j}=\hat{a}_{j-1}+K_{j}\left(q_{A C, j}-\varphi_{j} \hat{a}_{j-1}\right) \\
K_{j}=\frac{P_{j-1} \varphi_{j}{ }^{T}}{1+\varphi_{j} P_{j-1} \varphi_{j}^{T}} \\
P_{j}=P_{j-1}-\frac{P_{j-1} \varphi_{j}^{T} \varphi_{j} P_{j-1}}{1+\varphi_{j} P_{j-1} \varphi_{j}{ }^{T}}
\end{array}\right.
$$

ここで、次数 $p, q$ は不明である。この最適次数は次式で定義され る $A I C$ を最小化し推定する16, 17。

$A I C=N \log \sigma_{e}^{2}+2(p+q)$

次数推定のプロセスは逐次ではなく適当な期間ごとにバッチ的に 行わねばならない。モデルが定常であれば最適な次数は年間一定と なるが、実際には内部発熱の変動や風速変動による熱負荷への影響 を無視したモデルのため、経年的・季節的にモテルの次数が変化す る可能性がある。従って、次数が安定するまでは初動期間に次数の 見直しを行い、モデル次数の検討を行いながらモデルを構筑してゆ く必要がある。

将来の熱負荷は式(10)を用い、雑音を零 $\left(\varepsilon_{j}=0\right)$ として予测す る。ここで、外気温、日射量、外気のエンタルピーなどは気象デー 夕の予测により既知である。しかし、第 2 項に関保する室温は非空 調時間帯に未知となる。非空調時は熱負荷は零で、外気取り入れも ないため、式(10)の左辺と右辺第 5 項は零である。これから非空調時 の室温を求める次式が得られる。

$$
\begin{aligned}
\theta_{R, j}=\frac{1}{a_{A, 0}}\left(\sum_{L}\right. & \sum_{p=0}^{p} a_{T, L, p} \theta_{0, L, j-p}+\sum_{q=1}^{q} a_{A, q} \theta_{R, j-q} \\
& \left.+\sum_{L} \sum_{r=0}^{r} a_{S, L, r} J_{L, j-r}+a_{R} \zeta_{R, j}\right)
\end{aligned}
$$

因みに、本式は時系列解析の分野でARXモテルと呼ばれる。

通常、4後 9 時に明日の天気予報の情報を得て次の日の気象デー 夕を予测し、それを用いて、まず式(14)により非空調時の室温を逐次 求め、午前 8 時頃に空調が開始されると式(10)を用いて熱負荷を予测 する。これが一般的な予測のプロセスである。
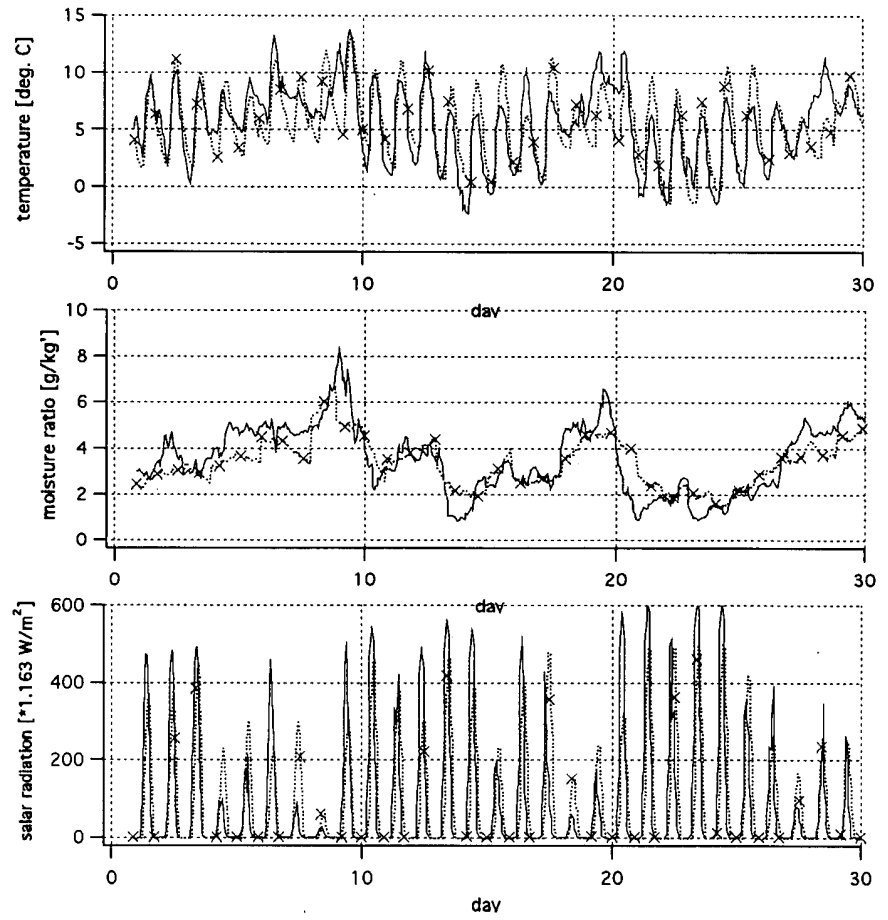

図-2.1 1985年 2 月1日〜3月2日の気象データ予測結果 上から、気温、湿度（混合比）、水平面全天日射

実線：計測結果、点線：予測值
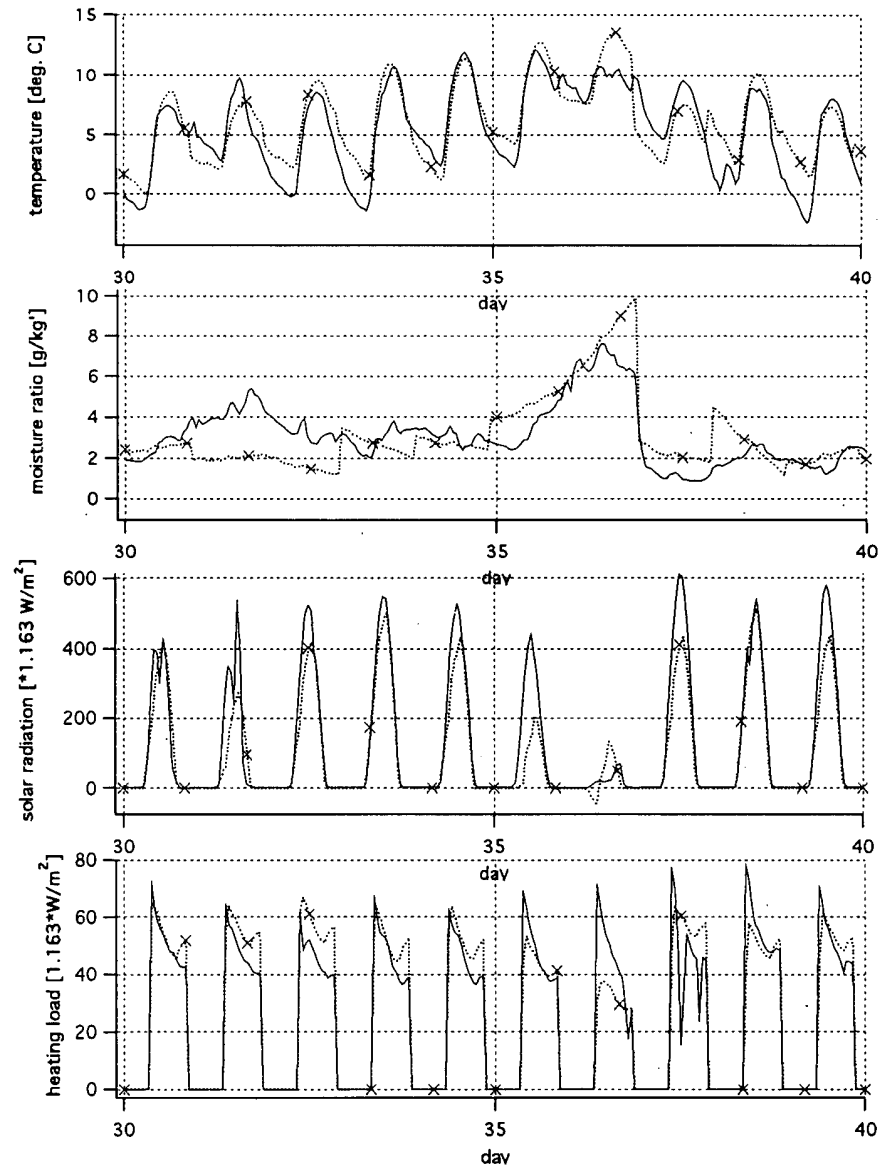

図-2.2 1994年 2 月15日 24の気象と熱負荷予測結果 上から、気温、湿度（混合比）、水平面全天日射、熱負荷 実線: 計测結果、点線 : 予测值 
3. 応用例

秦野に建つTビルで観測された值を利用して本手法の 性能を桱討した ${ }^{14)}$ 。本建物では予測をリアルタイムに行 い、その結果が実際に最適な運転への情報として用いら れている。

まず、気象データの予測の例を示す。図-2.1には1985 年の冬期（2月1日〜3月2日）の例を、また図-2.2では、 より詳細に日プロファイルを見るため、1994年の冬期 （2月15日〜24日）の例を示す。

表-4には上記期間の他に、1984年と1993年の夏期の予 测を加えて計 4 シーズンの予測の精度を誤差の標準偏差 として示す。1984,5年と1993,4年では10年の時間差があ り予報の確度が向上していることが期待できるが、結果 からは日射において若干良くなっている程度で大差ない ことが判る。なお、参照地と現地の気象を関係づける俰 数は表-1を用い、更新は行っていない。

図-3には、前日午後9時の天気予報を用いて24時間先 までの時刻別熱負荷を予测した結果から日積算熱負荷を 算出した值を示す。図-3.1は1994年の冬期（1月3日〜2月 27日）、図-3.2は1993年の夏期（7月20日〜9月10日）の 結果である。冬期は熱負荷の平均が2992 J に対し誤差の 標準偏差は328 J で、相対誤差は $12.2 \%$ あるる。夏期は平 均 $3719 \mathrm{~J}$ に対して偏差が $1067 \mathrm{~J}$ で相対誤差 $29 \%$ であ る。モテルの最適次数は式(10)の右辺第一項から順に冬 期が $(2,2,2,1,1)$ ，夏期が $(4,4,4,1,1)$ であった。

予測誤差は気象データの予测誤差によるものと、式 (10)による熱負荷の予測誤差によるものに分解できる。 そこで気象が完全に予测できたとして熱負荷を予测する ことで両者の笴与を分離してみた。その結果、夏期・冬期とも、気 象予測による誤差が1/3程度、熱負荷モデルによる予测誤差が $2 / 3$ 程度 となった。

図-2.2の最下段には1994年冬期10日間の予測值の時刻プロファイル を示す。実测値と合致しないものもあるが、大きな推定誤差は見ら れない。実测値に突発的な変化が見られる日があるが、この原因は 定かでなく、推定の立場からは雑音と呼ぶべき性質のものとしてし か扱えないようである。

\section{4. 結論}

蓄熱槽を合理的に運転するために不可欠な情報である翌日の熱負 荷を予測する手法を提案し、実際の建物の観測値に適用してその性 能を調べた。以下に本研究の結論と成果を列記する。

1) 熱負荷の予測を行うのに、天気予報による気象デー夕予测とそ れを用いた熱負荷予测という 2 段階の方法を提案した。本モテ ルは時系列の分野でARXモデルと呼ばれる形のモデルを一部に 用いているが、熱負荷計算の手順に比較的近い棈造を意図して おり、その意味ではブラックボックスモデルではなくフィジカ ルモデルと言うことができる。

2 ）熱負荷予測の安定度、精度の確認を実際の熱負荷テータを用い て行った。本例で示した結果によれば、冬期の予测熱負荷誤差 は約 $12 \%$ 、夏期は29\%で夏期に問題がある。内部発熱が熱負荷

\begin{tabular}{l|ccc}
\hline \multicolumn{1}{c|}{ 期間 } & 気温 & 湿度（混合比） & 日射 \\
\hline $1985.2 .1 \sim 3.2$ & 2.29 & 0.90 & 79.60 \\
$1994.1 .26 \sim 2.24$ & 2.29 & 1.36 & 64.40 \\
& & & \\
$1984.6 .26 \sim 7.27$ & 2.27 & 2.71 & 110.70 \\
$1993.8 .1 \sim 8.28$ & 2.49 & 2.77 & 99.20
\end{tabular}

表-4 気象データ予測の誤差（誤差の標準偏差）

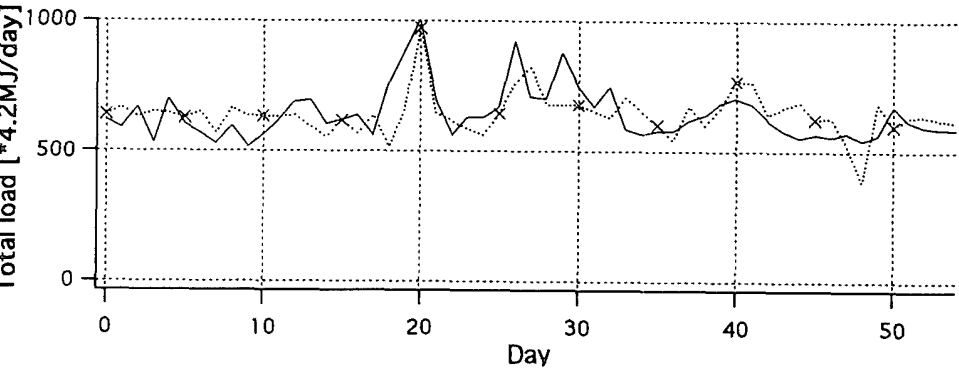

図-3.1 熱負荷予測の日棈算値（1994年1月3日〜2月27日）

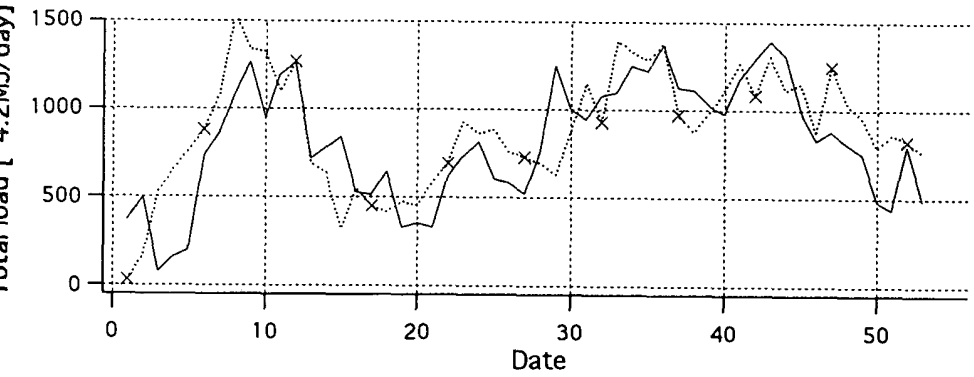

図-3.2 熱負荷予測の日積算值（1993年 7月20日～9月10日）

-3 熱負荷予測の日積算値 実線：計測結果、点線：予測值 （予測は前日の午後9時に行い予測の日積算値を熱負荷として示す。）

に大きく笴与することが大きな嵹差の原因でもあろう。しか し、本例で用いた期間は夏としては気象の変動が激しい冷夏の 気象であり、ある意味ではさほど精度は低くないとも言える。 今後、他の手法との比較・検討が必要と考える。

3）予测が気象予測と熱負荷予測と分離されているため、モデルの 誤差がどちらに起因するかが調べ易い。本報で示した例では全

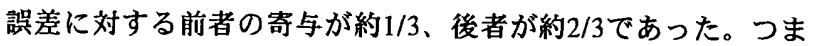
り、天気予報の精度が $100 \%$ になれば予测誤差は $1 / 3$ 程度減ずる言 える。

4）2.手法で述べたように、本方法は他の多くの方法と異なり空調の 運転時間が不定期であっても原理的には対応可能である。ただ し、本報で具体的な㭘討はしていないので今後検討を行いた W。

5 ) 本手法は計測データから予測を行うだけではなく、本予測アル ゴリズムを実際の建物に導入し、その予测の基に蓄熱システム が運転されたという実績がある。このことは本手法が十分実用 的に応用できることを示している14)。

本研究で報告した熱負荷の予測は蓄熱槽の合理的運転管理に不可 欠の条件ではあるが十分条件ではない。つまり、熱負荷の予測に基 づいていかに運転するかは、蓄熱槽からの熱損失、電気料金の体 系、取り出し水温の決定など冷凍機やヒートポンプの運転方法、 等々多くの問題が残されていると考える。 
謝辞：本研究に用いた観測デー夕は東京電力の営業所で実測された ものである。快くデータの提供許可を頂いた（株）東京電力と、本 手法を実際の建物に適応するに当たり本手法に関して多くの指摘を 頂いた日建設計・猪岡诖夫氏には記して感謝の意を表します。ま た、天気区分と日射量の関係は片岡卓氏（元京都大学建築学科学 生・現、間組）の協力を得て作成したものであることを付記する。

参考文献

1）吉田他、「蓄熱槽の合理的運転のための熱負荷予測」、日本建 築学会大会学術講演梗概集、pp. 1617〜 1618、1992

2）吉田、「蓄熱槽運転のための熱負荷予测」、空気調和・衛生工 学会学術講演会講演論文集、pp. 69〜72、1992

3）木村、「空調のコンピュータ制御のための負荷予測の一方 法」、日本建築学会大会学術講演梗概集・計画系、pp. 247〜 248, 1972

4）中原他、「空気調和設備の最適化制御について・その7」、日本 建築学会大会学術講演梗概集・計画系、pp. 287〜288、1976

5）相楽、「蓄熱空調システムの熱負荷予測に関する研究」、日本 建築学会計画系論文報告集、No. 440、pp.11〜20、1992

6）金原他、[ARIMAモデルによる空調熱負荷予椡」、計測自動 制御学会論文集、Vol. 26、No. 6、pp.721～728、1990

7) J.W.MacArthur、「On-Line Recursive Estimation for Load Profile Prediction」 、ASHRAE Transactions Vol. 95, pp.621 628, 1989
8）神村他、「空調熱負荷の実用化」、計测自動制御学会論文集、 Vol. 27、No.7、pp.827〜833、1991

9）長井他、「熱負荷の短期的予测手法に関する研究」、大会学術 講演梗概集、pp. 997〜998、1991

10）塩谷他、「（その1）夜間蓄熱運転のための日積算熱負荷予測へ の適用性の检討」、大会学術講演梗概集、pp. 131 132、1995

11)川島他、「Hourly Thermal Load Prdiction fort he Next 24 Hours by ARIMA, EWMA, RLR and Artmcial Network」、ASHRAE Transactions Vol. 101(1), pp 186 200, 1995

12）吉田他、「熱負荷計算用気象テータのモテル化 - 気温の日周期 成分についての検討」、日本建築学会論文報告集、No. 391 、 pp.39 49、1988

13）吉田他、「気象データの時系列モデルと確率的熱負荷に関する 研究」、日本建築学会計画系論文集、463号、pp. 11 19、1994

14）猪岡他、「蓄熱式空調システムの制御方式に関する研究（第 3 報）」、空気調和・衛生工学会学術講演会講演論文集、pp. 1577 80、 1994

15)「ティィジタル信号処理ハンドブック（システム推定）」、電子情 報通信学会、オーム社、1994

16)「計数・測定」、得丸他、培風館、1982

17)「空気調和・衛生工学便覧第12版、1.基礎編、2.11 時系列モテ ル」、吉田（分担執筆）、空気調和・衛生工学会、1995

(1996年 9 月 9 日原稿受理，1997年 1 月21日採用決定） 